\title{
Properties of Silicon Slag in Cement Mortar
}

\author{
Aline Heloá de Souza, Regina P. da Silva, and Gladis Camarini
}

\begin{abstract}
The building construction is considered one of the largest consumers of natural raw materials and the production of iron generates about $0.75 \mathrm{t}$ of slag per ton of pig iron produced. It is known that the natural resources are finite and the Brazilian National Policy on Solid Waste, becomes mandatory to give a destination for solid waste than to dispose them in landfill sites. This research was proposed to study the use of silicon slag to replace natural sand in mortars. The mortars were produced with $0 \%, 25 \%, 50 \%, 75 \%$ and $100 \%$ of replacement of the natural sand to silicon slag, by mass. The tests were consistency, compressive and flexural strength, capillary water absorption, and air permeability. The mortars with silicon slag had good results and showed that it can replace natural sand in mortars.
\end{abstract}

Index Terms —Mortar, recycling, silicon slag, waste.

\section{INTRODUCTION}

About $40 \%$ of natural resources are consumed by construction industry [1]. Thus, alternatives that reduce extraction of these resources are paramount, like the use of industrial waste as artificial aggregates instead of using natural aggregates [2], [3].

In Brazil the National Policy on Solid Waste establishes an order of priority for allocation of waste generated from any nature, aimed at reducing the environmental impact caused by the waste. This order of priority would be no generation, waste reduction, reuse, recycling, treatment and environmentally sound disposal of waste [4].

Silicon is used in various industries as raw material, like: information technology in the production of optical fibers and semiconductor industry, the steel industry for production of steel and aluminum alloy; solar energy in photovoltaic cells and fine chemicals in the production of silicones [5]. In the fabrication of those products silicon slag is generated.

The slag is composed basically by mixing the oxides $\mathrm{CaO}$, $\mathrm{Al}_{2} \mathrm{O}_{3}$ and $\mathrm{SiO}_{2}$ [5]. In Brazil, for each ton of pig iron there is the production of 0.75 tonnes of slag [6]. The production of slag exceeds 3 million tonnes, without considering the slag that has been stored over the years [6].

Due to the large amounts of generated silicon slag and the need for the right disposal of this waste, many studies have been developed by incorporating various types of slag in mortar and concrete in order to achieve improvements in the

Manuscript received April 5, 2014; revised June 6, 2014. This work was supported in part by the School of Civil Engineering and Urban Design at University of Campinas, UNICAMP, and by the National Council of Technological and Scientific Development - CNPq - Brazil.

The authors are with the Departament of Civil Engineering, Architecture and Urbanism (FEC), State University of Campinas - UNICAMP, Campinas, SP, Brazil (e-mail:alinesouza@aspb.arq.br, regina.pedronidasilva@gmail.com, camarini@fec.unicamp.br). physical and mechanical properties.

It was developed a survey incorporating granulated blast furnace slag on mortar used for restoration of old buildings [7]. This type of mortar is usually composed of brick or ceramic waste powder and lime. However, these researchers replaced milled powder ceramic residue by blast furnace slag at $0 \%, 10 \%, 20 \%, 30 \%$ and $40 \%$, in mass. They added $15 \%$ of lime as binder and used a lime/water ratio of $1 / 2$. The best results were obtained with increasing slag content, and the mixture of ceramic powder residue and slag. This indicates that the smaller voids improve the resistance.

Another study evaluated the replacement of natural sand by copper slag in high performance concrete [2]. They studied eight different mixtures with $0 \%, 10 \%, 20 \%, 40 \%$, $50 \%, 60 \%, 80 \%$ and $100 \%$ of copper slag replacement. The best workability results were obtained with the increasing percentage of slag. The compressive strength results increased with $50 \%$ slag incorporation. This same performance was observed to the water absorption by the replacement of $40 \%$ of the sand [2].

A study was developed to replace the sand by blast furnace slag in mortar [8]. The authors evaluated the incorporation of $0 \%, 25 \%, 50 \%, 75 \%$ and $100 \%$ of this waste replacing the sand with a 1:3 ratio and water cement ratio of 0.5 . They obtained results which enable the incorporation of slag mortar up to $75 \%$, while the best results were achieved with $25 \%$ substitution.

From these examples it can be noted that the behavior of different types of slag in mortars and concretes is different. Therefore, it is necessary to increase the studies in this theme

This study aims to evaluate the mortar performance when sand is replaced by silicon slag in different contents.

\section{MATERIALS AND METHODS}

In this research were used the cement CPV ARI, natural river sand and silicon slag. These materials were tested following the Brazilian Standards and the results are shown in Table I.

TABLE I: MATERIALS CHARACTERIZATION

\begin{tabular}{lllll}
\hline \hline Materials & $\begin{array}{l}\text { Specific } \\
\text { Gravity } \\
\left(\mathrm{kg} / \mathrm{m}^{3}\right)\end{array}$ & $\begin{array}{l}\text { Bulk Unit } \\
\text { weight } \\
\left(\mathrm{Kg} / \mathrm{m}^{3}\right)\end{array}$ & $\begin{array}{l}\text { Maximum } \\
\text { diameter } \\
(\mathrm{mm})\end{array}$ & $\begin{array}{l}\text { Fineness } \\
\text { modulus }\end{array}$ \\
\hline $\begin{array}{l}\text { Natural river } \\
\text { sand }\end{array}$ & 2.60 & 1.60 & 2.40 & 1.82 \\
Silicon slag & 2.57 & 1.57 & 4.75 & 3.24 \\
\hline \hline
\end{tabular}

\section{A. Mixture Preparation and Proportions}

The mortar cement: sand proportion was $1: 3$ and water/cement ratio 0.5 . The sand replacement was $0,25,50$, 
75 , and $100 \%$ of silicon slag, by mass, and named T0, T25, T50, T75 and T100, respectively.

The specimens were cylindrical, with $50 \mathrm{~mm}$ diameter and $100 \mathrm{~mm}$ height. The specimens were molded using a vibrating table. After molding the specimens remained in molds for 24 hours. They were demolded and immersed in water for curing until the age of the tests (7, 28 and 90 days).

\section{B. Consistency of Mortar}

Workability of fresh cement mortar was measured by using the flow table (Fig. 1) on the report by NBR 13279 (Brazilian Norm). The flowability results are shown in Table II.

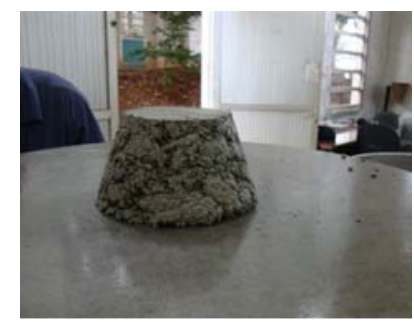

Fig. 1. Flow table test.

\section{Compressive and Tensile Strength}

The compressive strength (Fig. 2) and Brazilian Test (Fig. 3 ) at 7, 28, and 90 days.

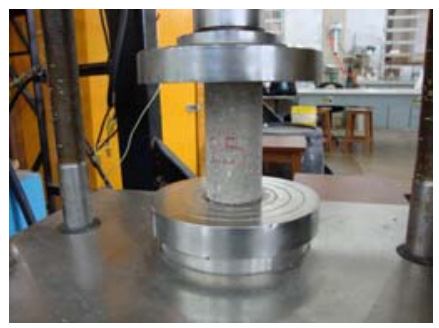

Fig. 2. Compressive strength test.
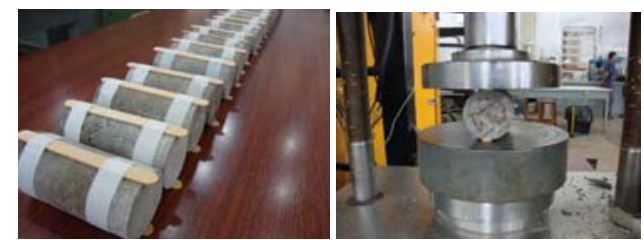

Fig. 3. Brazilian Test

\section{Total Absorption Test}

The total absorption test, the specimens were placed in an oven at a temperature of $100^{\circ} \mathrm{C}$ for 24 hours. Afterwards, they were removed from the oven, cooled, and were weighted (dry weight). The specimens were immersed in water for 24 hours and weighted (saturated weight).

The total water absorption was the difference of mass Saturated and dry. (Eq. (1)).

$$
\frac{(M s a t-M d) \times 100}{M d}
$$

where:

Msat - Saturated Mass

Md - Dry Mass

\section{E. Capillary Water Absorption Test}

The Capillary water absorption test measured the capacity of water to penetrate into the mortar. For this test, cylindrical specimens with dimensions $50 \mathrm{~mm}$ diameter $\mathrm{x} 100 \mathrm{mmm}$ height were used. The specimens stayed in a kiln for 24 hours at a temperature of $35^{\circ} \mathrm{C}$. After this step, they were cooled and a layer of waterproofing was applied in the lateral surface area. After the waterproofing resin has dried, the specimens were placed in a container with metal bracket in the bottom, which purpose is to prevent contact between the specimens and the bottom of the container. Finally, they were immersed in a constant water level about $5 \mathrm{~mm}$ above the bottom face in contact with water (Fig. 4). The specimens were weighted after $5,10,15,30,60,120,240,360,480$ and 1440 minutes. The capillary water absorption was calculated by the mass of water absorbed divided by the cross sectional area in contact with water (Fig. 5).

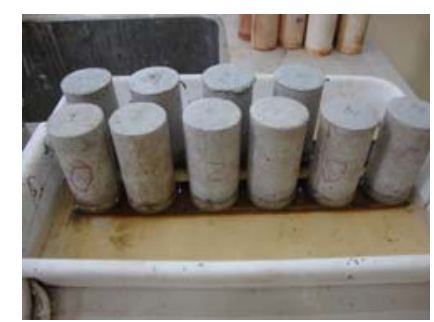

Fig. 4. Capillary water absorption test.

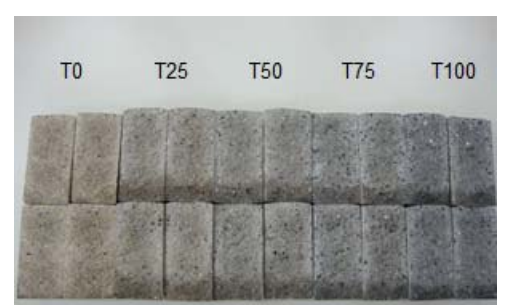

Fig. 5. Water rise of specimens.

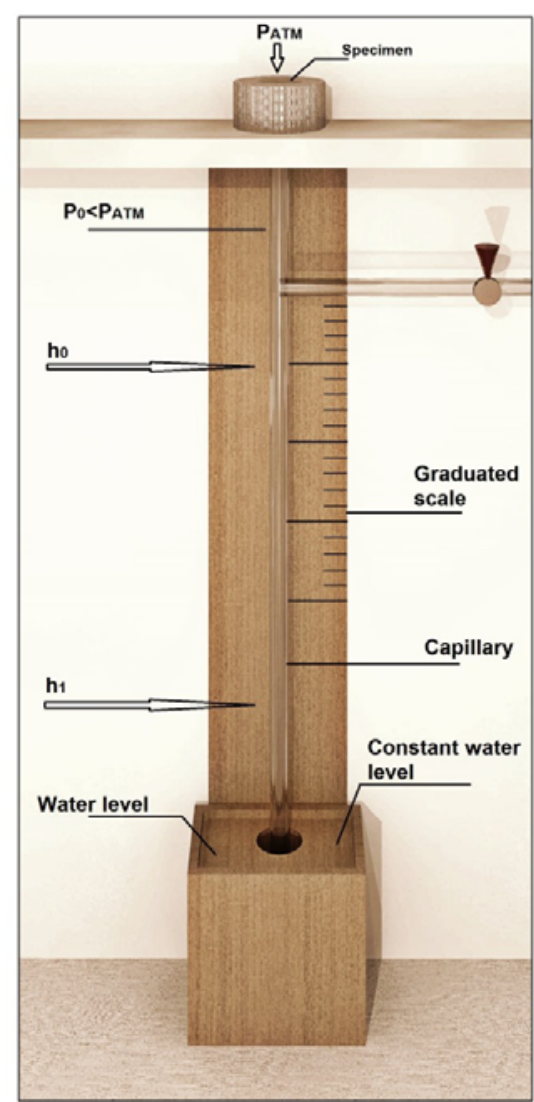

Fig. 6. Air permeability test apparatus. 


\section{F. Air permeability Test}

The air permeability test was performed according to the method of Thenoz. This consists in measuring the specimen's air permeability as a function of the time. The air flows through the specimens, creating a pressure in a tube, that promotes the vertical movement of the liquid located on the height $h_{0}$ to $h_{1}$ (Fig. 6).

\section{RESULTS AND DISCUSSION}

\section{A. Consistency}

The Table II shows the workability of fresh mortars. The mortars $T_{0}$ and $T_{25}$ did not workability results because they were very dry. The best result was to $T_{100}$ mortar. These results were expected, according to [9].

\section{B. Compressive and Tensile Strength}

Fig. 7 and Fig. 8 present the compressive strength and tensile strength results. The mixture with $100 \%$ of silicon slag had the highest results, and all mortars had increased the resistance with time.

Nataraja et al [8] obtained the best performance of mortars with $25 \%$ of slag replacement. In this research the mortar T25 obtained the worst result. This indicates that it is important to continue the researches using silicon slags as aggregate in mortars.

TABLE II: CONSISTENCY RESULTS

\begin{tabular}{cc}
\hline \hline \multicolumn{2}{c}{ Workability of fresh cement mortar } \\
\hline Mortar & Average results $(\mathrm{mm})$ \\
T0 & - \\
T25 & - \\
T50 & 165.50 \\
T75 & 172.50 \\
T100 & 205.50 \\
\hline \hline
\end{tabular}

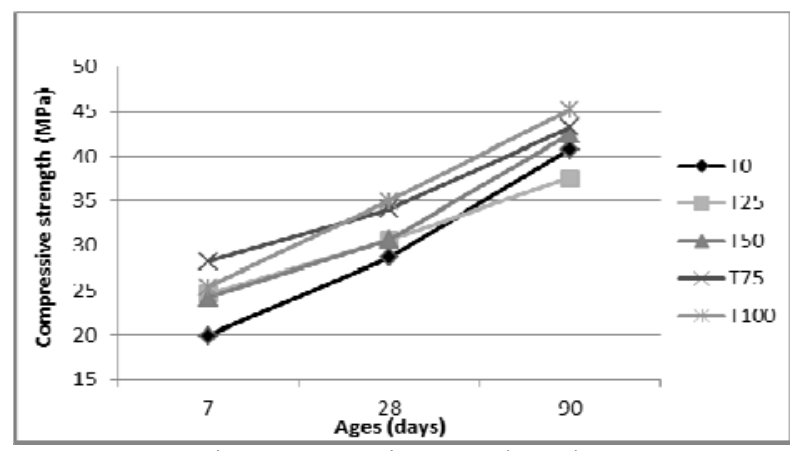

Fig. 7. Compressive strength results.

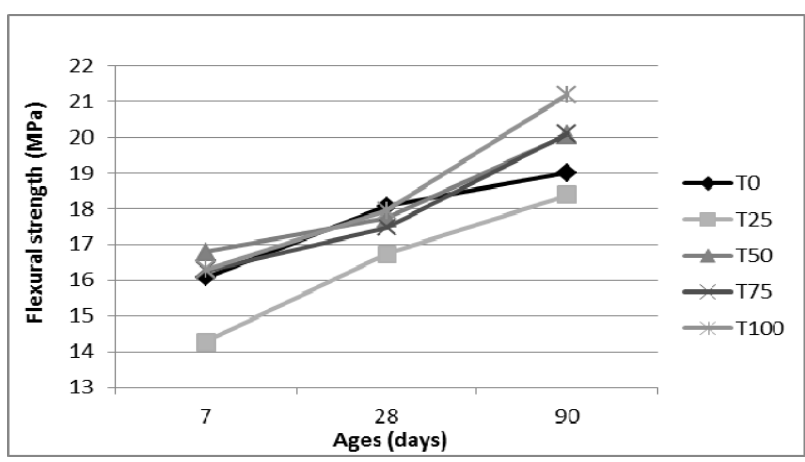

Fig. 8. Tensile strength results.

\section{Capillary and Total Water Absorption Tests}

Fig. 9 shows the total water absorption results, and the Fig. 10-11 show the capillary water absorption results. The age influence this property of the mortar and when the silicon slag content was increased, the mortar absorbed less quantity of water.

$T_{100}$ with greater silicon slag content decreased $15 \%$ of water absorption compared to $T_{0}$. The $T_{100}$ had good durability performance.

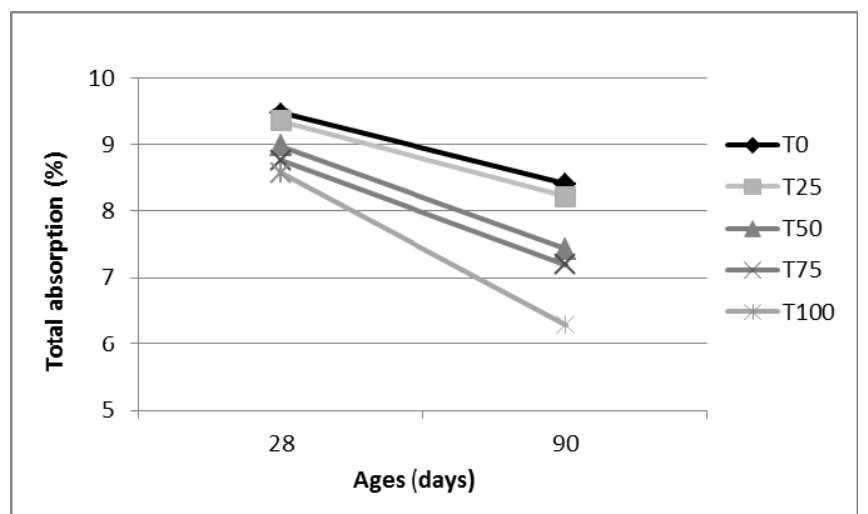

Fig. 9. Total water absorption results.

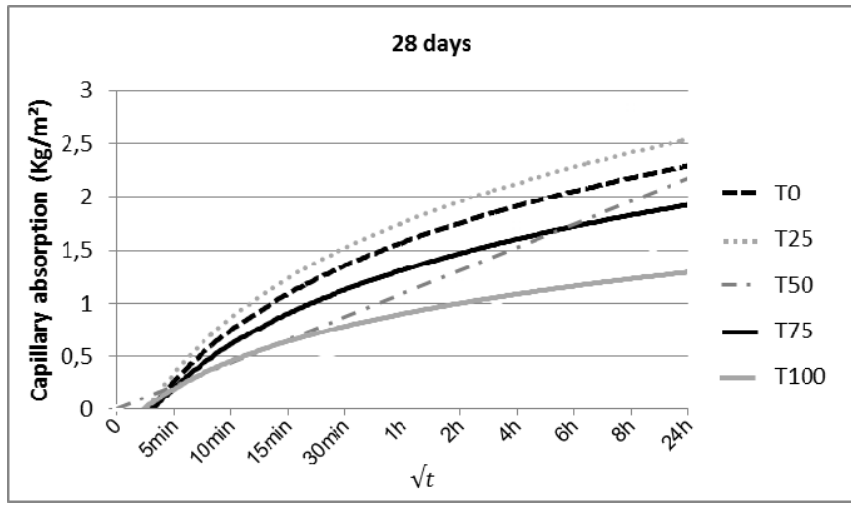

Fig. 10. Capillary water absorption results at 28 days.

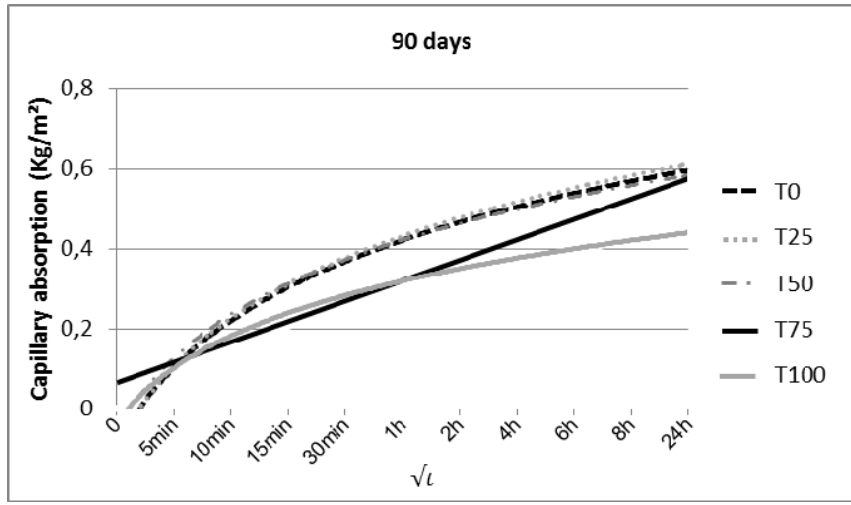

Fig. 11. Capillary water absorption results at 90 days.

\section{Air permeability}

Fig. 12 shows the air permeability test results. This test provides the durability of cement-based materials [10]. The lower the permeability the greater is the durability of mortar [11].

The $T_{25}$ had higher air permeability and $T_{0}$ had lower air permeability. According to the literature, the air permeability decreases with increasing compressive strength, but the obtained results in this research they are not consistent with the literature [12]. This parameter must be better 
investigated.

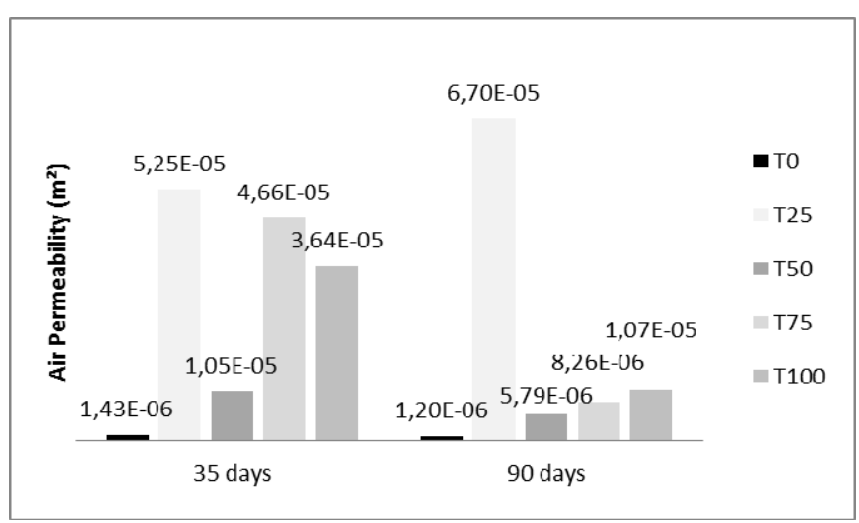

Fig. 12. Air permeability results.

\section{CONCLUSION}

The aim of this work was the use of silicon slag to replace natural sand and evaluate the performance of mortars.

The obtained results showed that it is possible to use silicon slag as aggregate in mortars, because the mechanical and durability results are satisfactory.

The replacement of $100 \%$ of natural sand by silicon slag had the best results

As this kind of waste does not have an appropriate destination, its using in mortars is an alternative to have an environmental sound disposal, and to reduce the need for extraction of sand for the production of mortars.

\section{REFERENCES}

[1] H. Arslan, N. Cosgun, and B. Salgin. (2012). Construction and Demolition Waste Management in Turkey, Waste Management - An Integrated Vision. [Online]. Available: http://www.intechopen.com/books/waste-management-an-integrated-v ision/construction-and-demolition-waste-management-in-turkey

[2] K. S. A. Jabri, M. Hisada, S. A. Oraimi, and A. H. A. Saidy, "Copper slag as sand replacement for high performance concrete," Building and Environment, vol. 31, pp. 483-488, August 2009.

[3] A. Rao, K. N. Jha, and S. Misra, "Use of aggregates from recycled construction and demolition waste in concrete," Building and Environment, vol. 50, pp. 71-81, March 2007.

[4] Establishing the National Solid Waste Policy creates the Interministerial Committee of the National Solid Waste Policy and Steering Committee for the Implementation of Reverse Logistics Systems, and other Measures. [Online]. Available: http://presrepublica.jusbrasil.com.br/legislacao/1026318/decreto-7404 $-10$

[5] W. Mendes and C. K. Suzuki, "Characterization of slags and recovery of silicon," PhD. dissertation, University of Campinas. Campinas, SP, 2003.

[6] A. A. Vidal, "Slag steelmaking in culture of rice: silicon source and the interaction with the nitrogen," PhD. dissertation, University of Julio de Mesquita Filho. Jaboticabal, SP, 2008.

[7] B. Isikdag and I. B. Topçu, "The effect of ground granulated blast-furnace slag on properties of Horasan mortar," Construction and Building Materials, vol. 40, pp. 448-454, March 2013.
[8] M. Nataraja, P. Kumar, and M. Sanjay, "Use of Granulated Blast Furnace Slag as Fine Aggregate in Cement Mortar," International Journal of Structural and Civil Engineering Research, vol. 2, no. 2, May 2013.

[9] A. E. B. Cabral, V. Schalch, D. C. C. D. Molin, and J. L. D. Ribeiro, "Performance estimation for concretes made with recycled aggregates of construction and demolition waste of some Brazilian cities," Materials Research, vol. 15, no. 6, pp. 1037-1044, September 2012.

[10] V. M. Pereira and G. Camarini. "Air permeability of concrete by Thenoz method," Advanced Materials Research, vol. 224, pp. 132-136, 2011.

[11] G. Camarini et al., "Methods to measure the transfer properties of mortars," Applied Mechanics and Materials, vol. 148-149, pp. 184-187, 2012.

[12] M. V. Pereira, "Air permeability of concrete," $\mathrm{PhD}$. dissertation, University of Campinas. Campinas, SP, 2011.

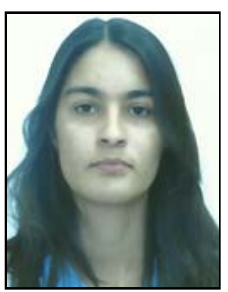

Souza A. H. was born in Sorocaba-SP (Brazil), in 1989. She graduated in civil engineering at Faculty of Engineering Sorocaba - FACENS on December 2012. Currently she is a student of masters the State University of Campinas - UNICAMP, she is working as a civil engineer in LEMAT - Laboratory Testing of Materials, and as a professor of civil engineering at FACENS. Aline has of 5 years experience in the area of materials, including research and testing of new products. During graduation she developed a research project on the influence of the additive throttle grip in the early ages of concrete.

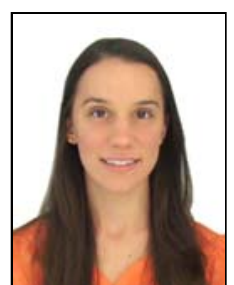

Regina P. da Silva was born in Campinas-SP in 1989. She graduated in environmental engineering at Pontifical Catholic University of Campinas on December 2011.

She has been working for CBFT environmental consulting in Campinas-SP (Brazil) for two years, with environmental licensing. During her graduation she worked as an intern in the same company and for the company Petróleo Brasileiro S.A., in the Environment Department of the refinery Paulinia-SP (Brazil). Besides these developed an scientific iniciation study to the incorporation of construction waste in concrete blocks and published the article "Study of the Composition of Mortars Containing Waste Construction," in Journal of the Brazilian Concrete Congress (Ibracon 2009), along with Lintz, RCC and Pugliero, V.S.

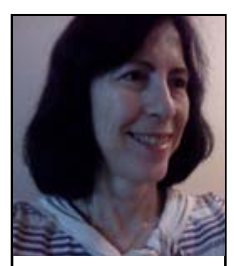

Gladis Camarini is a civil engineer and a professor at School of Civil Engineering, Architecture and Urban Design, University of Campinas. She had her master degree in 1988 and $\mathrm{PhD}$. degree in 1995 at University of São Paulo. She did postdoctoral studies at the Laboratoire des Materiaux et Durabilité des Constructions (LMDC) at Institut National des Sciences Apliquées (INSA, Toulouse, France, 1998). She also did postdoctoral studies at the National Institute for Space Research (INPE, São José dos Campos, Brazil, 2008). Then she also did postdoctoral studies at the Institute of Science and Technology del Hormigón (ICITECH), the Polytechnic School of Valencia (UPV) (Valencia, Spain, 2012). She is a peer reviewer of scientific journals indexed on the Journal Citation Reports, national and international journals, Congress and Seminars, and Brazilian Research Foundations. She is an IACSIT senior member. Her research interests include: building materials, mineral binders, mortars, industrial and construction wastes, reusing and recycling of materials, mortar, concrete, and other composites. 